\title{
Erratum to: Evidence from the Chernobyl Nuclear Accident: The Effect on Health, Education, and Labor Market Outcomes in Belarus
}

\author{
Maksim Yemelyanau • Aliaksandr Amialchuk • \\ Mir M. Ali
}

Published online: 31 January 2012

(C) Springer Science+Business Media, LLC 2012

\section{Erratum to: J Labor Res \\ DOI 10.1007/s12122-011-9122-9}

Unfortunately, an error is present in the reference to Fig. 1. It should read "....Source: Pacini et al. (1997). ..." instead of "....Source: Pacini et al. (1998). ...". The reference is also given below.

Pacini et al. (1997) Post-Chernobyl Thyroid Carcinoma in Belarus Children and Adolescents: Comparison with Naturally Occurring Thyroid Carcinoma in Italy and France. The Journal of Clinical Endocrinology and Metabolism, vol. 82 no. 11, pp. 3563-3569

The online version of the original article can be found at http://dx.doi.org/10.1007/s12122-011-9122-9.

M. Yemelyanau

CERGE-EI, P.O. Box 882, Politických vězňů 7, Prague 111 21, Czech Republic e-mail: maksim.yemelyanau@gmail.com

A. Amialchuk $(\bowtie)$

Department of Economics, University of Toledo, Toledo, OH 43606-3390, USA

e-mail: aamialc@utnet.utoledo.edu

M. M. Ali

Department of Economics, University of Toledo \& Office of Regulations, Policy and Social Science, Food \& Drug Administration, College Park, MD 20740, USA

e-mail: mir.ali@fda.hhs.gov 